Diabetologia $10,225-231(1974)$

(C) by Springer-Verlag 1974

\title{
Peripheral Blood Flow and Metabolic Control in Juvenile Diabetes
}

\author{
H.J.G. Gundersen \\ Second University Clinic of Internal Medicine, University of Aarhus, Denmark \\ Received: September 17, 1973, and in revised form: February 25, 1974
}

\begin{abstract}
Summary. Peripheral blood flow was measured during periods of good and poor metabolic control in juvenile diabetics with less than five years duration of the disease. Previously insulin treated patients, in whom the insulin was withdrawn for a few days, showed elevated blood flow in muscular, adipose and cutaneous tissue, whereas a group of newly diagnosed diabetics before treatment showed elevated blood flow in adipose and cutaneous tissue only. In good metabolic control the diabetics had normal values of both muscular, adipose and cutaneous tissue blood flow. In poorly controlled diabetics blood
\end{abstract}

pressure, pulse rate and body temperature were elevated. These parameters are also normalized when the metabolism is brought under control. It is suggested, that the increased peripheral blood flow seen in diabetics in poor control is the effect of a generally increased turn-over of energy in combination with local factors, different from tissue to tissue.

Key words: Adipose tissue blood flow, metabolic control, muscle blood flow, normalization of metabolism, skin blood flow.
During the past few years some authors have found higher tissue blood flow in diabetics, most often in the forearm [6, 3, 9], but also in adipose tissue [13]. However, the degree of metabolic control was not well defined in these studies.

The present investigation was undertaken in order to study the relationship between the elevated peripheral blood flow and the metabolic disturbance in diabetics.

It is clearly demonstrated, that diabetics have normal blood flow in muscle, skin and fat tissue during good control. Furthermore, it is shown, that changes in some of the important parameters of the circulation are related to metabolic factors characteristic of the diabetic condition during poor control.

\section{Material and Methods}

Eighteen patients (three of them females) with classic juvenile diabetes were studied, their age ranging from 17 to 35 years, mean age 23 years. Seven of them (two females) were admitted with newly diagnosed diabetes. They were investigated before treatment was started and again on one or several occasions during treatment with insulin and diet. The other 11 patients (one female) were diabetics with 9 months to 5 years duration of disease, who had been treated with insulin and diet all that time. These patients were hospitalized for the specific experimental purpose. After having been investigated in clinically well controlled conditions their insulin was withdrawn for a few days under carefully clinical and biochemical supervision. The measurements were carried out during the deterioration of their metabolism. Most of them were also investigated one or two times after the reestablishment of the insulin treatment. None of the patients were allowed to develop clinical coma or precoma. The mean number of investigations per patient was four (ranging from two to seven), but only results from occasions where the individual patient was in his best and poorest control state will be considered in the present communication.

Nine healthy volunteers (four females) with age from 23 to 36 years, mean age of 25 years, served as controls. All patients and control persons had given their informed consent to participate in the study.

The measurements were performed in the morning: after an overnight fast. During treatment the diabetics were given their last dose of insulin the day before at 6 p.m. During each experiment blood samples were obtained two or more times through an indwelling venous catheter. Blood glucose was determined with a glucose-oxidase method [8] and free fatty acids in serum (FFA) with a titremetric micromethod [15]. The concentration of standard bicarbonate (st- $\mathrm{HCO}_{3}{ }^{-}$), potassium, and sodium in serum, the urinary glucose content and the haematocrit value were determined with routine laboratory methods.

The subjects were at rest, lying on a bed, for at least one hour before the measurements were initiated. They were dressed in underwear and shirt and covered with one or two blankets, depending on their subjective feeling of thermal comfort.

Total forearm blood flow was measured with a mercury-in-rubber strain gauge employing the venous occlusion principle. The blood flow was measured every $10 \mathrm{sec}$ for two minutes on five to ten occasions distributed over a two to four hour period. The forearm blood flow is the mean of these $50-100$ individual measurements and is expressed in $\mathrm{ml}$ of blood per $100 \mathrm{ml}$ of tissue per minute $(\mathrm{ml} / 100 \mathrm{ml} / \mathrm{min})$.

Abdominal fat tissue blood flow was measured by the clearance of 133-Xe [14] employing a distribution 
coefficient of Xenon between blood and fat tissue of 10.0 in the calculations.

Blood flow in cutaneous and subcutaneous tissue was measured on the proximal third of the dorsal side of the forearm after atraumatic gaseous $133-\mathrm{Xe}$ labelling [18], using distribution coefficients of Xenon of 0.7 and 10.0, respectively. The blood flow in both tissues is expressed in $\mathrm{ml} / 100 \mathrm{ml} / \mathrm{min}$.

The blood pressure was measured with a sphygmomanometer, and is expressed as the mean blood pressure, i.e. diastolic pressure + one third of the pulse amplitide. The blood pressure was usually measured in every interval between the two-minutes periods of forearm blood flow measurements.

The pulse rate was calculated from the plethysmographic recordings of forearm blood flow.

The body temperature was measured on the tympanic membrane. This organ is perfused from the internal carotic artery and its temperature therefore reflects that of the heat regulating centre in hypothalamus [5]. This temperature as well as the cutaneous temperature on the forearm and the abdomen was measured with thermistors to the nearest decigrade of Celcius. The room temperature was 21 to $24^{\circ} \mathrm{C}$. or even in a state of cloudy consciousness. The values of the four biochemical parameters, on which the evaluation of the degree of control was based and of serum-K are shown in Table 2. The figures show the extreme situation in the individual patient, i.e. they are from occasions in which that particular patient was in respectively the best and the poorest degree of regulation. It appears that there is no difference between blood glucose, $\mathrm{FFA}$, st- $\mathrm{HCO}_{3}-$ or the urinary glucose excretion observed in the two groups of diabetics, the newly diagnosed cases and the patients who had previously been on insulin treatment. However, when the serum- $K$ values of these two groups are compared a clearcut difference appears. The average values in the poorest control state is $0.7 \mathrm{meq} / \mathrm{l}$ higher in the group of previously insulin treated patients than in the newly diagnosed ones, $2 \mathrm{P}=0.011$.

The same tendency is apparent when looking at the difference between the serum- $K$ values observed in the poorest and in the best state of control. In the previously insulin treated cases there was a difference of $0.4 \pm 0.5 \mathrm{meq} / \mathrm{l}$ (all patients) which was also statistically significant, $2 \mathrm{P}=0.044$. On the other hand, in the newly diagnosed cases where the serum- $K$ was low during poor control, there was no statistically signifi-

Table 1. Class limits employed in the calculation of the degree of regulation. For further explanation see text

\begin{tabular}{|c|c|c|c|c|c|}
\hline Class & 0 & 1 & 2 & 3 & 4 \\
\hline Blood glucose, $\mathrm{mg} / 100 \mathrm{ml}$ & $<100$ & $100-149$ & $150-224$ & $225-300$ & $>300$ \\
\hline Serum, FFA, $\mathrm{nM} / 1$ & $<400$ & $400-599$ & $600-849$ & $850-1199$ & $>1200$ \\
\hline Serum st- $\mathrm{HCO}_{3}-$ meq $/ 1$ & $>22$ & $22-21$ & $20-19$ & $18-15$ & \\
\hline Urinary glucose, g/24 h & 0 & $0-24$ & $25-74$ & $75-175$ & $>175$ \\
\hline
\end{tabular}

The skin fold on the forearm and the abdomen was estimated with Harperden's caliper at the places where the 133-Xe clearances were measured.

The degree of metabolic disturbance was evaluated on the basis of fasting blood glucose, FFA and st$\mathrm{HCO}_{3}$ - in serum and the $24 \mathrm{~h}$ urinary excretion of glucose. These four parameters were divided into five classes, shown in 'Table 1 . The metabolic disturbance at the time of investigation was then calculated as the arithmetic mean of the class numbers of the four parameters. This figure is called the patient's degree of regulation (DR). DR $\leqq 1$ is a very good control state, which is unusual in a juvenile diabetic, whereas a patient with $\mathrm{DR}=4$ probably will be in precoma or coma the next day.

\section{Results}

\section{Biochemical Parameters}

The range of metabolic control in the patients studied varied between almost complete normalization and moderate ketoacidosis with st- $\mathrm{HCO}_{3}-$ of $10 \mathrm{meq} / \mathrm{l}$. None of the patients in poor control were unconscious cant difference between the values in poor and best control: $-0.3 \pm 0.6 \mathrm{meq} / 1$ (all patients) $2 \mathrm{P}=0.16$.

The haematocrit value was determined as a rough measure of dehydration. The difference between values obtained in the best and in the poorest state of control was quite small and nearly identical in the two groups of patients. It was $2 \%$ higher during poor control in the newly diagnosed patients, $3 \%$ higher in the previously insulin treated cases.

\section{Blood Flow Measurements}

The results of the blood flow measurements in the forearm and the other tissues will be considered from three different points of view, endeavouring to answer the following three questions: a) is the blood flow in various organs abnormal when the diabetic state is very good controlled? b) is there a demonstrable difference between blood flow in good and poor control as defined by the composite four parameter index used in the present study? c) can a relationship be shown between blood flow and any individual biochemical parameter measured?

Forearm Blood Flow. The forearm flow was measured in all patients and control subjects. 
a) Fig. 1, A shows the total forearm blood flow values in the control subjects and in those patients in the two groups of diabetics in whom it was measured at times when the $\mathrm{DR} \leqq 1$. There is neither any difference between the normals and the diabetics in very this difference is statistically highly significant, whereas the newly diagnosed showed no difference between the untreated and the best regulated condition. The mean changes in the two groups of diabetics were statistically significantly different, $2 \mathrm{P}=0.024$.

Table 2. Values of biochemical parameters in diabetics in their best and poorest control, defined on the basis of the calculated degree of regulation in the individual patient

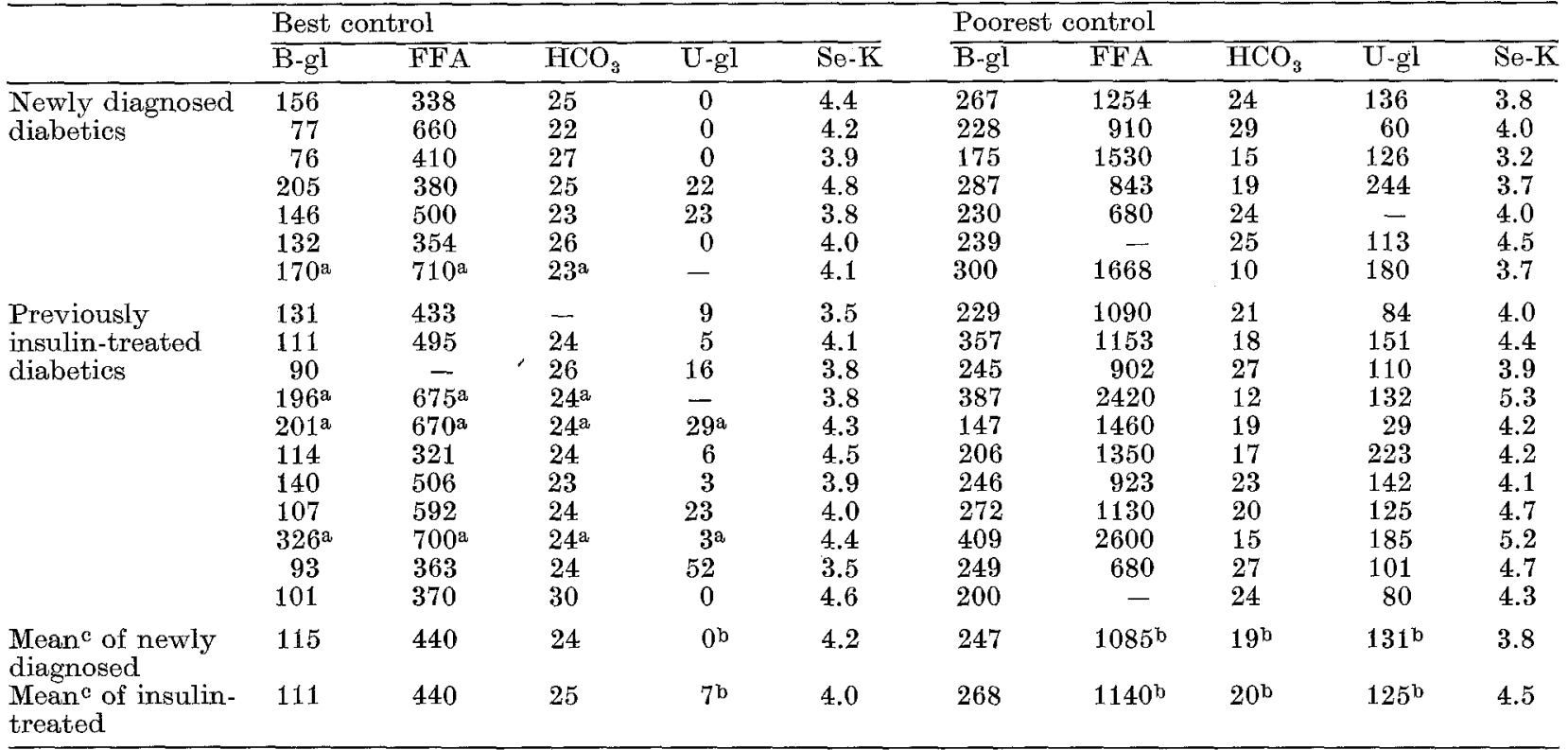

B-gl: Blood glucose, $\mathrm{mg} / 100 \mathrm{ml}$

FFA: Free fatty acids in serum, $n M / l$

$\mathrm{HCO}_{3}:$ Standard bicarbonate, meq/1

U-gl: 24 h urinary glucose excretion

Se-K: Potassium in serum, meq/l

a $\mathrm{DR}>1$ in best control

b Median

c In "Best control" only patients with very good control (i.e. DR $\leqq 1$ ) are included.

Table 3. Average blood flow in the various tissues in normals and very good controlled diabetics. The mean difference between flow values in the poorest and the best control state in the individual diabetic and its level of statistical significance are also shown

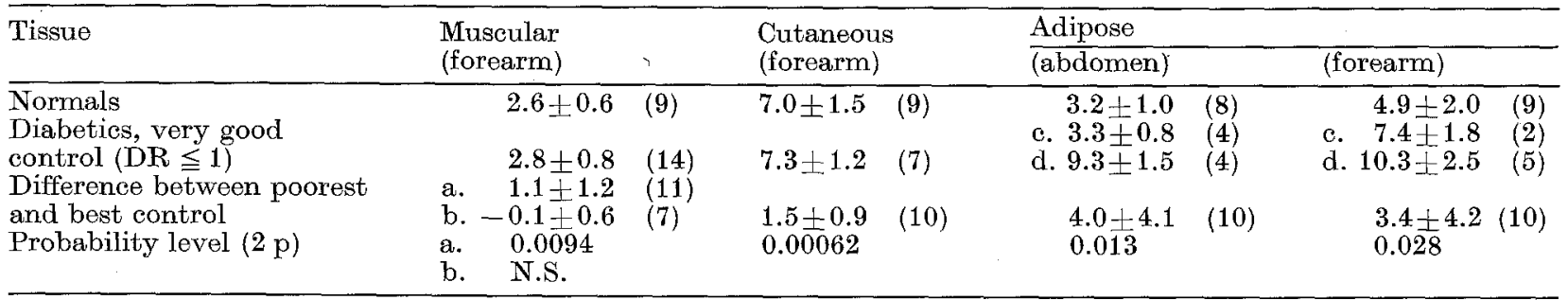

a. Mean \pm S.D. (N)

a. previously insulin treated diabetics

b. newly diagnosed diabetics

c. normal skinfold thickness

d. skinfold thickness less than normal.

good control (see Table 3), nor between the previously insulin treated $(2.6 \pm 0.9 \mathrm{ml} / 100 \mathrm{ml} / \mathrm{min})$ and the newly diagnosed diabetics $(3.1 \pm 0.6 \mathrm{ml} / 100 \mathrm{ml} / \mathrm{min})$.

b) Fig. 1, B and Table 3 show the difference be. tween poor and good regulation in all diabetics in the two groups. In the previously insulin treated diabetics
Correlation analysis in both groups of diabetics did not show relationships between any of the individual biochemical parameters including serum- $K$ on the one hand, and absolute flow value in the poorest state of control or the difference between blood flow in poor and good control on the other. 
Cutaneous Blood Flow. The cutaneous blood flow was measured in 10 diabetics, seven of whom had a $\mathrm{DR} \leqq 1$ in best control.

a) These very good controlled diabetics showed the same mean cutaneous blood flow as the nine normals, see Fig. 2, A and Table 3.

b) Fig. 2, B and Table 3 show that the difference

$A$

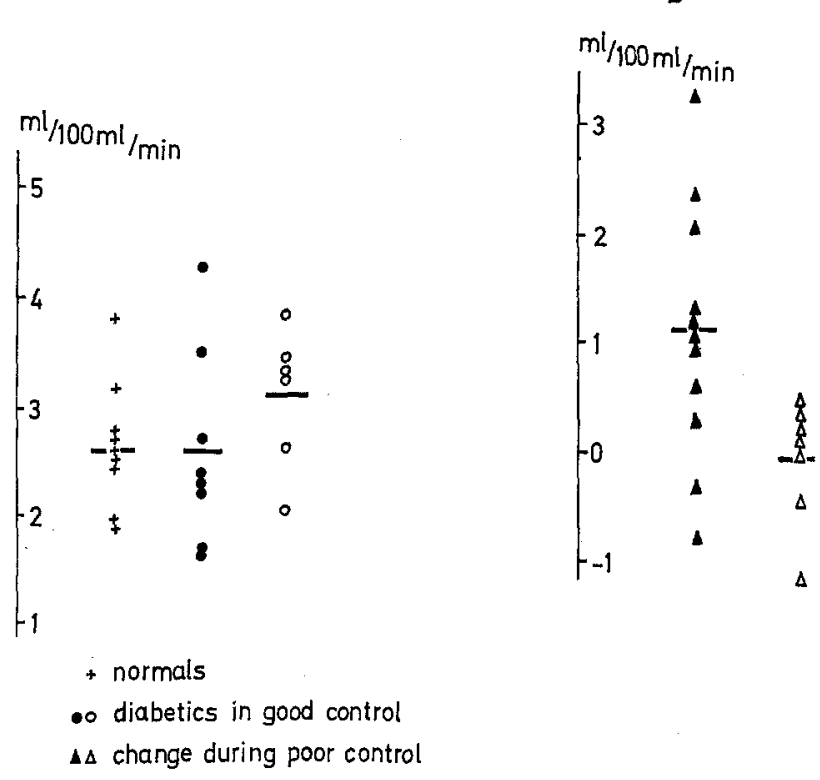

Fig. 1. A) Forearm blood flow in normals and diabetics with degree of regulation $\leqq 1$. The blood flow is expressed in $\mathrm{ml} / 100 \mathrm{ml} / \mathrm{min}$. The filled circles represent the previously insulin treated diabetics, and the open circles represent newly diagnosed diabetics. $B$ ) The difference in forearm blood flow between poorest and best regulation in diabetics. The filled triangles are the previously insulin treated patients and the open triangles are newly diagnosed diabetics

in cutaneous blood flow measured in poor and good metabolic conditions in all 10 diabetics is statistically highly significant. The difference between poor and good regulation is equal in the two groups of diabetics.

c) As with forearm blood flow, correlation analysis did not reveal relationship between cutaneous blood flow and any individual biochemical parameter. However, there was a trend towards a correlation between the changes in body temperature and cutaneous blood How in the individual patient, $\mathrm{r}=0.65$, although not statistically significant.

Fat Tissue Blood Flow. The blood flow in the subcutaneous fat layer was measured both on the abdomen and on the forearm.

It is known that the local fat tissue blood flow is inversely related to the thickness of the skinfold at the point of measurements [14]. In order to make comparisons of blood flow, it is therefore necessary to select groups with approximately equal skinfold thickness. In the group of normals the thickness of the skinfold on the abdomen and the forearm was $14.7,7.2-22.9 \mathrm{~mm}$ (median and range) and 7.1, 4.9-8.1 $\mathrm{mm}$, respectively, whereas the figures in the diabetics with $\mathrm{DR} \leqq 1$ were $6.7,4.6-16.2 \mathrm{~mm}$ and $4.6,3.0-6.8 \mathrm{~mm}$. The values in the diabetics are statistically significantly lower than in the normals, $2 \mathrm{P}<0.05$ and $2 \mathrm{P}<0.01$ (Wilcoxon rank sum), respectively. Only diabetics with skinfold.
A

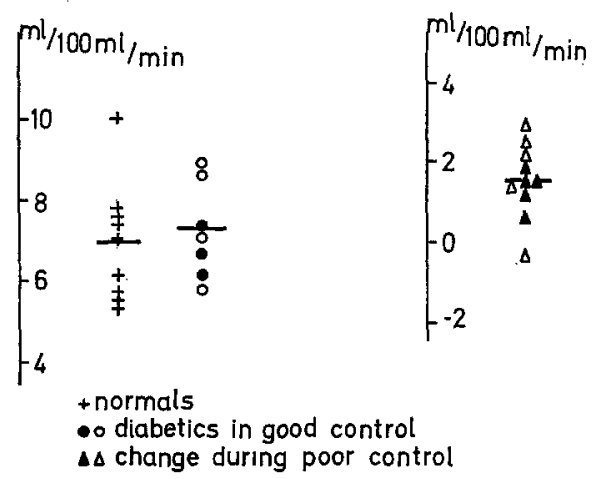

Fig. 2. A) The cutaneous blood flow in normals and in diabetics with degree of regulation $\leqq 1 . B$ ) The difference between cutaneous blood flow in the poorest and the best degree of regulation in diabetics. Symbols and units as previously

thickness greater than the leanest normal has been included in the comparisons of blood flow between diabetics and normals.

a) The mean blood flow in the abdominal subcutaneous fat tissue of four diabetics in very good control and with skinfold thickness $>7.2 \mathrm{~mm}$ was the same as that of the normals, see Fig. 3, A and Table 3.

Only two of the diabetics with $\mathrm{DR} \leqq 1$ had normal skinfold thickness of the forearm and showed blood flow values of the subcutaneous fat, which are comparable to that of the normal group.

b) Figs. 3, B and 4, B show the differences between the subcutaneous fat tissue blood flow on the abdomen and forearm, respectively, in poor and good control. Although the variances are great, both of the mean differences are statistically significant. The difference between the fat tissue blood flow in poor and good. control was equal in lean and "fat" diabetics.

c) Neither the subcutaneous fat tissue blood flow during metabolic derangement nor its changes were correlated to any of the individual biochemical parameters.

\section{Blood Pressure, Pulse and Body Temperature}

a) It appears from Table 4 that diabetics in very good control showed normal values of mean blood pressure, pulse rate and body temperature.

b) The values of these three parameters in poorest control are also shown in Table 4 . The average difference in all diabetics between poorest and best control 
with respect to mean blood pressure was statistically significant, $2 \mathrm{P}=0.016$. The difference in mean blood pressure was due to elevations in both diastolic (4.1 $6 \mathrm{mmHg})$ and systolic $(17 \pm 13 \mathrm{mmHg})$ blood pressure. Similar moderate but consistent differences were observed in pulse rate $(2 \mathrm{P}=0.0021)$ and in body temperature $(2 \mathrm{P}=0.0014)$.

A

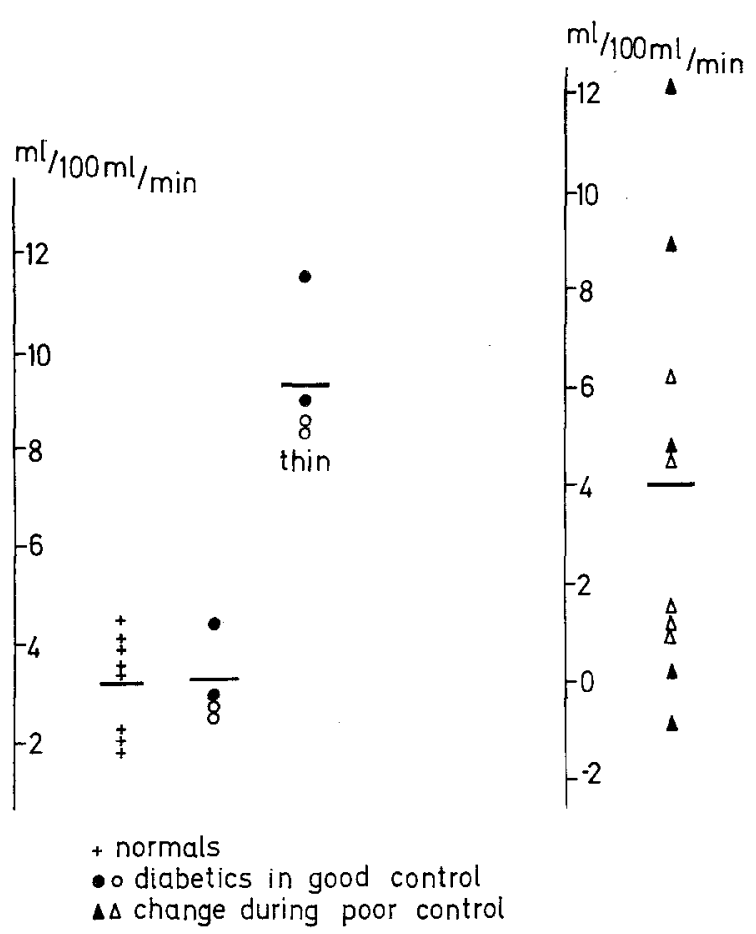

Fig. 3. A) Abdominal subcutaneous fat tissue blood flow in normals and in diabetics with degree of regulation $\leqq 1$. The thin diabeties have a skinfold thickness less than the lowest normal $(7.2 \mathrm{~mm})$, the other group of diabetics have skinfold values within the normal range. $B$ ) The difference in abdominal fat tissue blood flow between the poorest and best degree of regulation in diabetic patients. Symbols and units as in Fig. 1

The newly diagnosed diabetics showed the same elevations in all three parameters in poorest control as the previously insulin treated patients.

c) Statistical analysis revealed highly significant correlations between the differences in both mean blood pressure, pulse rate and body temperature on the one hand and the individual values of st- $\mathrm{HCO}_{3}{ }^{-}$and FFA in poorest control on the other hand, see Table 5. There was no correlation between the differences in any of the three parameters and the values of blood glucose and $24 \mathrm{~h}$ urinary glucose excretion in poorest control. The values of st- $\mathrm{HCO}_{3}-$ and $\mathrm{FFA}$ in poorest control were closely related to each other, $\mathrm{r}=-0.64,2 \mathrm{P}=$ 0.0042 , whereas the corresponding values of blood glucose and $24 \mathrm{~h}$ urinary glucose excretion were unrelated to st- $\mathrm{HCO}_{3}-$ and $\mathrm{FFA}$.

\section{Discussion}

The results obtained in the present study show that the blood flow of the forearm, the cutaneous tissue and the subcutaneous fat is elevated in poorly controlled diabetic patients after withdrawal of insulin. The same is true for the blood flow of cutaneous and subcutane-
A

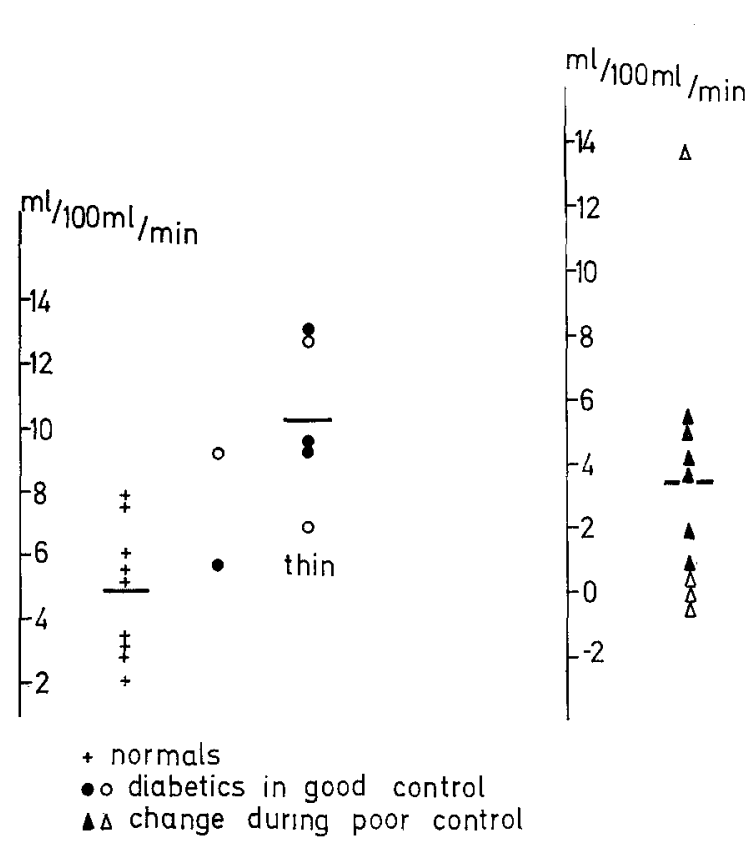

Fig. 4. A) Forearm subcutaneous fat tissue blood flow in normals and diabetic patients with degree of regulation $\leqq 1$. The thin diabetics have a forearm skinfold less than the lowest normal $(4.9 \mathrm{~mm})$ and the two other diabetics have skin fold thickness within the normal range. $B$ ) The differences in forearm subcutaneous fat blood flow between the poorest and best degree of regulation in diabetic patients. Symbols and units as in Fig. 1

ous fat tissue in newly diagnosed diabetics. When the metabolic state is brought under control by resumption, respectively by starting of insulin treatment the flow becomes normal.

Furthermore it was found that blood pressure, pulse rate and body temperature were elevated in poorly controlled diabetics. These parameters, too, are normalized when the metabolic state is brought under control.

Elevated forearm blood flow in diabetics has been described in some studies $[6,7,3,9]$, but the metabolic state of the diabetics were either abnormal at the time of investigation $[6,7,9]$ or not stated [3]. The flow has been shown to fall after 2-26 days of insulin treatment, but not to normal values [9].

The abdominal fat tissue blood flow has also been 
shown to be elevated in diabetics who were not wellcontrolled, and the flow was halved $30 \mathrm{~min}$ after insulin i.v. [13].

It thus appears that elevated blood flow in the forearm and the adipose tissue is a characteristic finding in diabetics when their state of metabolic control is poor, and that insulin treatment for hours or days will lower the elevated blood flow. temperature in combination with a high skin blood flow during metabolic derangement found in the present study is an indirect expression of the increased heat production. Similarly, the hypermetabolism in thyrotoxicosis is accompanied by an elevated muscle blood. flow that falls in parallel with the basal metabolic rate after treatment [2]. Furthermore, in a group of diabetics and normals a correlation between the local

Table 4. Blood pressure (B.P.), pulse rate and body temperature in normal subjects and diabetic patients in periods of best and poorest control, respectively

\begin{tabular}{|c|c|c|c|c|c|c|c|c|c|}
\hline & \multicolumn{3}{|c|}{ Normals } & \multicolumn{6}{|c|}{ Diabetics } \\
\hline & \multirow[b]{2}{*}{ B.P. } & \multirow[b]{2}{*}{ Pulse } & \multirow[b]{2}{*}{ Temp. } & \multicolumn{2}{|c|}{ Best control } & \multicolumn{4}{|c|}{ Poorest control } \\
\hline & & & & B.P. & Pulse & Temp. & B.P. & Pulse & Temp. \\
\hline Newly diagnosed & $\begin{array}{l}78 \\
77 \\
78 \\
76 \\
83 \\
93 \\
87 \\
80\end{array}$ & $\begin{array}{l}55 \\
59 \\
72 \\
61 \\
54 \\
73 \\
66 \\
75\end{array}$ & $\begin{array}{l}36.5 \\
36.5 \\
36.2 \\
36.9 \\
36.6 \\
36.1 \\
36.7 \\
-\end{array}$ & $\begin{array}{l}74 \\
78^{\mathrm{a}} \\
83 \\
87 \\
- \\
- \\
-\end{array}$ & $\begin{array}{l}62 \\
80^{a} \\
58 \\
71 \\
64 \\
74 \\
72\end{array}$ & $\begin{array}{l}36.5 \\
36.6^{a} \\
36.5 \\
36.7 \\
- \\
- \\
-\end{array}$ & $\begin{array}{l}79 \\
93 \\
83 \\
98 \\
- \\
- \\
-\end{array}$ & $\begin{array}{l}68 \\
89 \\
59 \\
80 \\
69 \\
90 \\
71\end{array}$ & $\begin{array}{l}36.7 \\
37.2 \\
36.6 \\
37.5 \\
- \\
- \\
-\end{array}$ \\
\hline $\begin{array}{l}\text { Previously insulin } \\
\text { treated }\end{array}$ & 79 & 56 & - & $\begin{array}{l}82 \\
81 \\
92 \\
80^{a} \\
65 \\
81 \\
87^{a} \\
- \\
- \\
- \\
-\end{array}$ & $\begin{array}{l}49 \\
63 \\
67 \\
65^{\mathrm{a}} \\
62 \\
57 \\
69^{\mathrm{a}} \\
64 \\
74^{\mathrm{a}} \\
81 \\
57\end{array}$ & $\begin{array}{l}36.4 \\
36.6 \\
36.8 \\
36.5^{\mathrm{a}} \\
36.6 \\
36.7 \\
36.6^{\mathrm{a}} \\
- \\
- \\
- \\
-\end{array}$ & $\begin{array}{r}90 \\
84 \\
88 \\
99 \\
74 \\
76 \\
101 \\
- \\
- \\
- \\
-\end{array}$ & $\begin{array}{r}60 \\
62 \\
70 \\
84 \\
74 \\
53 \\
109 \\
70 \\
102 \\
84 \\
65\end{array}$ & $\begin{array}{l}37.0 \\
37.0 \\
36.8 \\
36.7 \mathrm{c} \\
36.8 \\
36.7 \\
37.4 \\
- \\
- \\
-\end{array}$ \\
\hline $\begin{array}{l}\text { Mean }{ }^{b} \\
\text { SD }\end{array}$ & $\begin{array}{r}81 \\
7\end{array}$ & $\begin{array}{r}63 \\
8\end{array}$ & $\begin{array}{r}36.5 \\
0.3\end{array}$ & $\begin{array}{r}81 \\
8\end{array}$ & $\begin{array}{r}64 \\
8\end{array}$ & $\begin{array}{r}36.6 \\
0.1\end{array}$ & $\begin{array}{r}88 \\
9\end{array}$ & $\begin{array}{l}76 \\
15\end{array}$ & $\begin{array}{r}36.9 \\
0.3\end{array}$ \\
\hline
\end{tabular}

a $\mathrm{DR}>1$ in best control

b In "Best control" only patients with very good control (i.e. DR $\leqq 1$ ) are included

c The body temperature was measured on another occasion than the corresponding values of blood pressure and pulse rate.

Table 5. The coefficients of correlation calculated for the differences between poorest and best control in mean blood pressure, pulse rate and body temperature, respectively, on the one hand and the values of st- $\mathrm{HCO}_{3}^{-}$and $F \mathrm{FH}$ in serum in poorest control on the other hand

\begin{tabular}{lcc}
\hline & St-HCO & Se-FFA \\
\hline Mean blood pressure & $\mathrm{r}=-0.88$ & $\mathrm{r}=+0.86$ \\
$(\mathrm{n}=10)$ & $2 \mathrm{P}=0.0025$ & $2 \mathrm{P}=0.0051$ \\
Pulse rate & $\mathrm{r}=-0.60$ & $\mathrm{r}=+0.77$ \\
$(\mathrm{n}=15)$ & $2 \mathrm{P}=0.0081$ & $2 \mathrm{P}=0.00045$ \\
Body temperature & $\mathrm{r}=-0.73$ & $\mathrm{r}=+0.77$ \\
$(\mathrm{n}=10)$ & $2 \mathrm{P}=0.010$ & $2 \mathrm{P}=0.0048$
\end{tabular}

The normal blood flow in well controlled diabetics found in the present study shows that this progresses to complete normalization. when treatment is optimal. This finding suggests that the elevated blood flow is caused by one or more metabolic factors or by a factor closely related to the metabolism in diabetics.

It has been known for many years that the basal metabolic rate is elevated in diabetic patients, particularly under bad control $[4,11]$. The elevated body oxygen uptake and blood flow in both adipose and muscular tissue has been shown [12]. It thus seems reasonable to suggest that one of the reasons for the elevated peripheral blood flow in diabetics during poor control is an increased turn-over of energy in all tissues.

In addition, factors having specific effects on the blood flow in the individual tissues must also be considered. One such factor is probably the sympathetic nervous system. It has recently been shown [10] that the concentration of plasma noradrenaline is consistently raised in diabetics with ketosis, and that some patients in severe ketosis show very high levels of plasma adrenaline. The local effect of noradrenaline on fat tissue is an increase in both lipolysis and blood flow $[16,17]$, whereas the action of adrenaline is less well defined. In the skin, both catecholamines produce a reduction in blood flow, and the small but consistent elevation seen in diabetios in poor control must therefore be the result of a more potent opposing mechanism, most likely the thermo-regulatory response to the increase in body temperature. The effect of adrenaline 
on muscle is an increased blood flow, whereas noradrenaline produces a decrease [1]. The influence of catecholamines on the muscular blood flow in diabetics in poor control is therefore depending on the relative concentration of the two amines.

The finding of a normal muscular blood flow in the newly diagnosed, untreated diabetics in the present study was quite unexpected. The reason for the difference thus found between these patients and those in whom insulin treatment was stopped is not clear. The difference in serum-K between the two groups may be important.

The degree of elevation of local blood flows found in the present study indicates that the total peripheral resistance is low in poorly regulated diabetics. With a decrease in peripheral resistance, a rise in pulse rate is necessary to maintain blood pressure. The present results show, however, that blood pressure is not only unchanged, but slightly elevated. This clearly indicates that cardiac output is elevated and that the heart is stimulated by other factors in addition to the mechanism compensating the peripheral vascular dilatation. The increased activity in the sympathetic nervous system is most likely one of these factors.

\section{References}

1. Abramson, D.I. : Circulation in the extremities, p. 408. New York: Academic Press 1967

2. Abramson, D.I., Fierst, S.M.: Resting peripheral blood flow in the hyperthyroid state. Arch. intern. Med. 69, 409-416 (1942)

3. Alexander, K., Teusen, R., Mitzkat, H.J.: Vergleichende Messungen der Extremitätendurchblutung bei Diabetikern und Stoffwechselgesunden. Klin. Wschr. 46, 234-238 (1968)

4. Benedict, F.G., Joslin, E.P.: A study of metabolism in severe diabetes. Washington: Carnegie Institute 1912

5. Benzinger, T.H., Taylor, G.W.: Temperature, its measurement and control in science and industry. ch. 10. (Ed. Hertzfeld, C.M.). New York: Reinhold Publishing Corporation 1963
6. Butterfield, W.J.H., Holling, H.E.: Peripheral glucose metabolism in fasting control subjects and diabetic patients. Clin. Sci. 18, $147-174$ (1959)

7. Butterfield, W.J.H., Whichelow, M.J.: Peripheral glucose metabolism in control subjects and diabetic pationts during glucose, glucose-insulin and insulin sensitivity tests. Diabetologia 1, 43-53 (1965)

8. Christensen, N.J.: Notes on the glucose oxidase method. Scand. J. clin. Lab. Invest. 19, 379-384 (1967)

9. Christensen, N.J.: A reversible vascular abnormality associated with diabetic ketosis. Clin. Sci. 39, 539$548(1970)$

10. Christensen, N.J.: Diabetic angiopathy and neuropathy. Acta med. scand. Suppl. 541 (1972)

11. Holten, C.: The respiratory metabolism in diabetics and the influence of insulin upon it. (Thesis) Copenhagen: Levin and Munksgaard Publishers 1925

12. Häggendal, E., Kerstell, J., Steen, B., Svanborg, A. : Blood flow and uptake of oxygen and substrates in forearm muscle and subcutaneous fat tissue in man. Acta med. scand. 183, 79-82 (1968)

13. Häggendal, E., Steen, B., Svanborg, A.: Blood flow in subcutaneous fat tissue in patients with diabetes mellitus. Acta med. scand. 187, 49-53 (1970)

14. Larsen, O.A., Lassen, N.A., Quaade, F.: Blood flow through human adipose tissue determined with radioactive xenon. Acta physiol. scand. 66, 337-345 (1966)

15. Laurell, S., Tibbling, G.: Colorimetric microdetermination of free fatty acids in plasma. Clin. chim. Acta 16, 57-62 (1967)

16. Levin Nielsen, S., Bitsch, V., Larsen, O.A., Lassen, N.A., Quaade, F.: Blood flow through human adipose tissue during lipolysis. Scand. J. clin. Lab. Invest. 22, $124-130(1968)$

17. Quaade, F., Larsen, O.A., Lassen, N.A., Levin Nielsen, S.: Observations on the influence of glucose upon subcutaneous adipose tissue blood flow. Acta med. scand. Suppl. 476, 85-90 (1967)

18. Sejrsen, P.: Blood flow in cutaneous tissue in man studied by washout of radioactive xenon. Circulat. Res: 25, 215-229 (1969)

Dr. H.J.G. Gundersen

Second University Clinic of Internal

Medicine

Aarhus University

Aarhus

Denmark 